\title{
Correction to: The urinary microbiome shows different bacterial genera in renal transplant recipients and non-transplant patients at time of acute kidney injury - a pilot study
}

Daniela Gerges-Knafl ${ }^{*}$, Peter Pichler ${ }^{1}$, Alexander Zimprich², Christoph Hotzy ${ }^{2}$, Wolfgang Barousch ${ }^{3}$, Rita M. Lang ${ }^{4}$, Elisabeth Lobmeyr ${ }^{5}$, Sabina Baumgartner-Parzer ${ }^{4}$, Ludwig Wagner ${ }^{1}$ and Wolfgang Winnicki ${ }^{1}$

Correction to: BMC Nephrology (2020) 21:117 https://doi.org/10.1186/s12882-020-01773-1

Following publication of the original article [1], we were notified that an author's first and last name had been reversed.

Incorrect: Pichler Peter

Correct: Peter Pichler

The original article has been corrected.

\section{Author details}

${ }^{1}$ Department of Internal Medicine III, Division of Nephrology and Dialysis, Medical University of Vienna, Waehringer Guertel 18-20, 1090 Vienna, Austria. ${ }^{2}$ Department of Neurology, Medical University of Vienna, Vienna, Austria. ${ }^{3}$ Department of Laboratory Medicine, Division of Clinical Microbiology, Medical University of Vienna, Vienna, Austria. ${ }^{4}$ Department of Internal Medicine III, Division of Endocrinology and Metabolism, Medical University of Vienna, Vienna, Austria. ${ }^{5}$ Department of Emergency Medicine, Medical University of Vienna, Vienna, Austria.

Published online: 07 May 2020

\section{Reference}

1. Gerges-Knafl, et al. BMC Nephrol. 2020;21:117 https://doi.org/10.1186/ s12882-020-01773-1.

The original article can be found online at https://doi.org/10.1186/s12882020-01773-1.

* Correspondence: daniela.knafl@meduniwien.ac.at

${ }^{1}$ Department of Internal Medicine III, Division of Nephrology and Dialysis, Medical University of Vienna, Waehringer Guertel 18-20, 1090 Vienna, Austria Full list of author information is available at the end of the article

(c) The Author(s). 2020 Open Access This article is licensed under a Creative Commons Attribution 4.0 International License, which permits use, sharing, adaptation, distribution and reproduction in any medium or format, as long as you give appropriate credit to the original author(s) and the source, provide a link to the Creative Commons licence, and indicate if changes were made. The images or other third party material in this article are included in the article's Creative Commons licence, unless indicated otherwise in a credit line to the material. If material is not included in the article's Creative Commons licence and your intended use is not permitted by statutory regulation or exceeds the permitted use, you will need to obtain permission directly from the copyright holder. To view a copy of this licence, visit http://creativecommons.org/licenses/by/4.0/ The Creative Commons Public Domain Dedication waiver (http://creativecommons.org/publicdomain/zero/1.0/) applies to the data made available in this article, unless otherwise stated in a credit line to the data. 